\title{
New insights on the tectonic evolution of the Miocene gap grabens of Sers-Siliana (Tunisian Atlas) during Neogene to Quaternary: Contribution of chronology of the regional tectonic events
}

\author{
N Mahmoudi ${ }^{1}, *$, F Ferhi $^{1}, \mathrm{Y} \mathrm{Houla}^{2}, \mathrm{R} \mathrm{AzizI}^{3}$ and L Chiнi ${ }^{1}$ \\ ${ }^{1}$ Department of Earth Sciences, Faculty of Sciences of Bizerte, Carthage University, 7021 Jarzouna-Bizerte, Tunisia. \\ ${ }^{2}$ Department of Earth Sciences, National Office of Mines, 2035 Charguia, Tunisia. \\ ${ }^{3}$ Department of Earth Sciences, Faculty of Sciences of Gafsa, Gafsa University, Gafsa, Tunisia. \\ *Corresponding author. e-mail: noureddine_m1@yahoo.com
}

MS received 26 March 2018; revised 5 March 2019; accepted 25 April 2019; published online 12 July 2019

The NW-SE trending grabens of Sers-Siliana, located in the Central Tunisian Atlas, show a peculiarity, compared to adjacent grabens, which comes from the existence of an early Miocene sedimentary gap. This paper discusses the structural evolution of these grabens, during the Neogene-Quaternary episode, which have been poorly studied in previous studies. To better understand the chronology of the two grabens, a set of direct and indirect pieces of evidence are given in order. The results show that the collapse is of Aquitanian-Tortonian age which is synchronous with the regional collapse of the Alpine chain foreland grabens. In addition, our field observations show that the E-trending faults affect the incompetent materials (marls) and assured the mechanical junction between these two grabens. The chronology of tectonic events, during the Neogene-Quaternary time, in the Sers-Siliana area coincides with that described at the regional scale for the Tunisian Atlas domain, allowing a better understanding of the role played by the convergence between African and Eurasian plates.

Keywords. Tunisian Atlas; Neogene; upper Tortonian; quaternary; subduction.

\section{Introduction}

The convergence of the African and Eurasian plates is at the origin of the Maghreb and Atlas chain structuring (Cohen et al. 1980; Chihi and Philip 1998; Piqué et al. 2002; Bouaziz et al. 2002; Nocquet and Calais 2004; Essid et al. 2016). The Tunisian Atlas shows NW-SE to E-W trending grabens, located in the North Maghrebian chain foreland (Ben Ayed 1986; Philip et al. 1986; Boukadi 1994; Chihi 1995; Dlala 1995; Belguith et al. 2011; Melki et al. 2011; Dhahri et al. 2015) and organised in relays, breaking up the Atlas platform into a series of raised and collapsed panels (figure $1 \mathrm{a}$ and $\mathrm{b}$ ).

These structures (grabens) are adjacent to the NE-trending fold axis as originated during the Atlassic phase (late Miocene). Some authors consider that these folds have been formed during the late Miocene and were reactivated at lower Pleistocene before being cut up during Quaternary by normal faults (Castany 1948; Richert 1971; Ben Ayed 1975). In contrast, subsequent investigations in the Tunisian Atlas domain based on tectonic and microtectonic studies proved that the graben collapse is anterior to the late Miocene compressional 

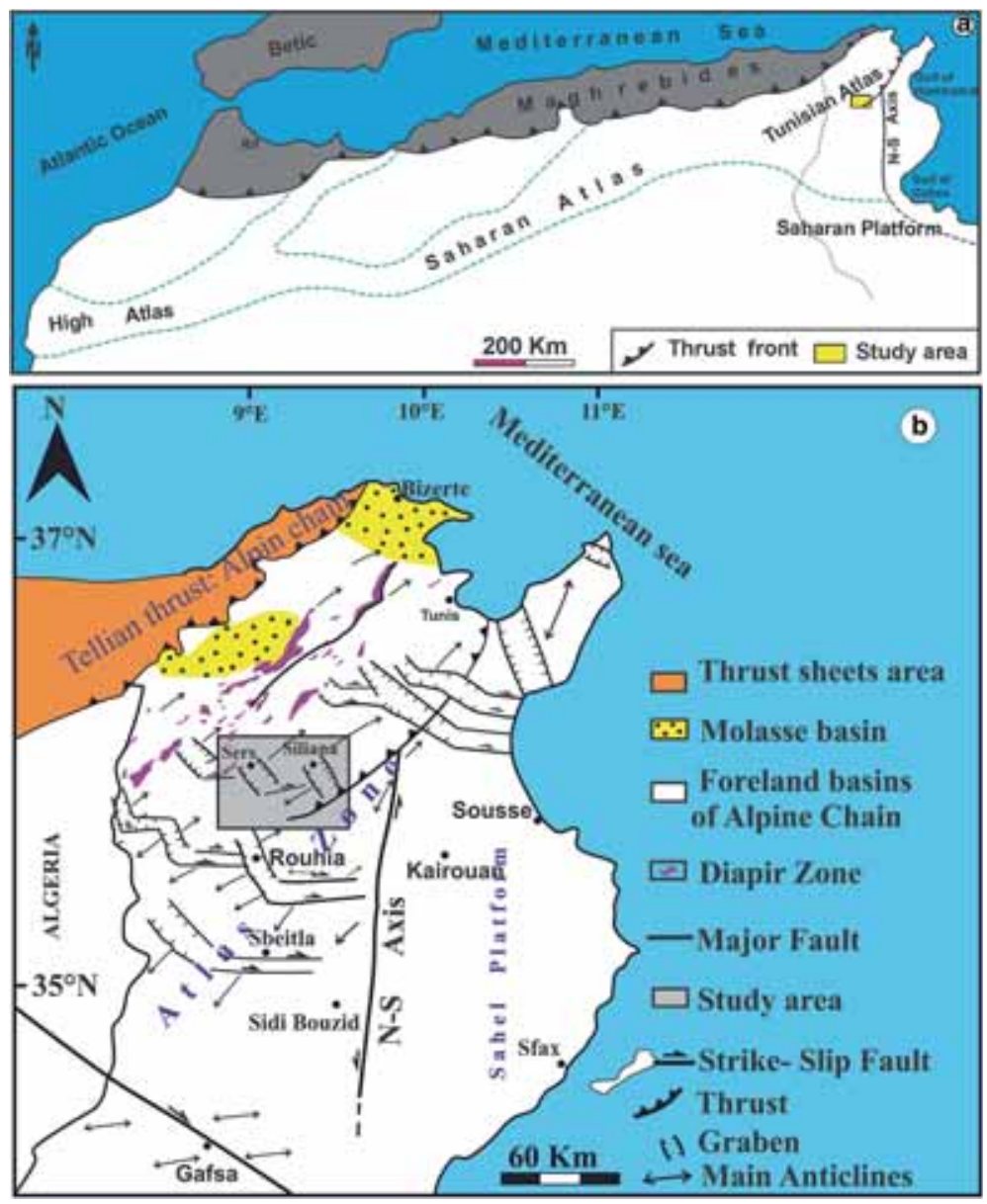

Figure 1. (a) Structural setting of the eastern Maghrebian zone showing the deformed Atlassic domain and (b) location of Sers-Siliana area in the Tunisian Atlassic domain.

phase (Ben Ayed 1986; Philip et al. 1986, Chihi 1995; Dlala 1995; Azizi et al. 2015). Our present study concerns the NW-trending Sers-Siliana grabens. These extensional structures are distinguished from adjacent grabens by the lack of Miocene deposits in most of the Siliana-Sers regions except some rare outcrops located SW of the Jebel Lorbeus and Siliana graben (figure 2).

These structures have been the subject of numerous studies (Castany 1948; Jauzein 1967; Richert 1971; Ben Ayed 1975; Karoui-Yaakoub et al. 2002; Haji et al. 2014; Mahmoudi et al. 2016). Some authors (Castany 1948; Jauzein 1967; Richert 1971; Ben Ayed 1975) suggested that the Sers and Siliana grabens formed during the PlioQuaternary and are isolated basins. The age and structure, proposed by the previous studies, do not coincide with the age of the rest of the grabens and basins in the foreland basins of the Tunisian Alpine chain.

The present study examines the structural evolution of these two grabens during the Neogene-Quaternary episode, which has been described in the previous studies as having formed during the Plio-Quaternary episode and as being two-isolated basins (Castany 1948; Jauzein 1967; Richert 1971; Ben Ayed 1975; Caire 1977). In this study we present new structural arguments and detailed geological mapping of the central Tunisian Atlas (Sers-Siliana area). Integrating these data with the reappraisal of published chronological data carried out in the Tunisian Atlas domain, we reconstruct the structural evolution of the Sers and Siliana grabens during Neogene-Quaternary. Our results document that the structural evolution of the Sers-Siliana area was controlled, at a large scale, by the convergence between the African and Eurasian plates at that time.

\section{Structural and geological setting}

The structural framework of the Atlas mountain belt of North Africa is integrated within the geodynamic evolution of the western Mediterranean 


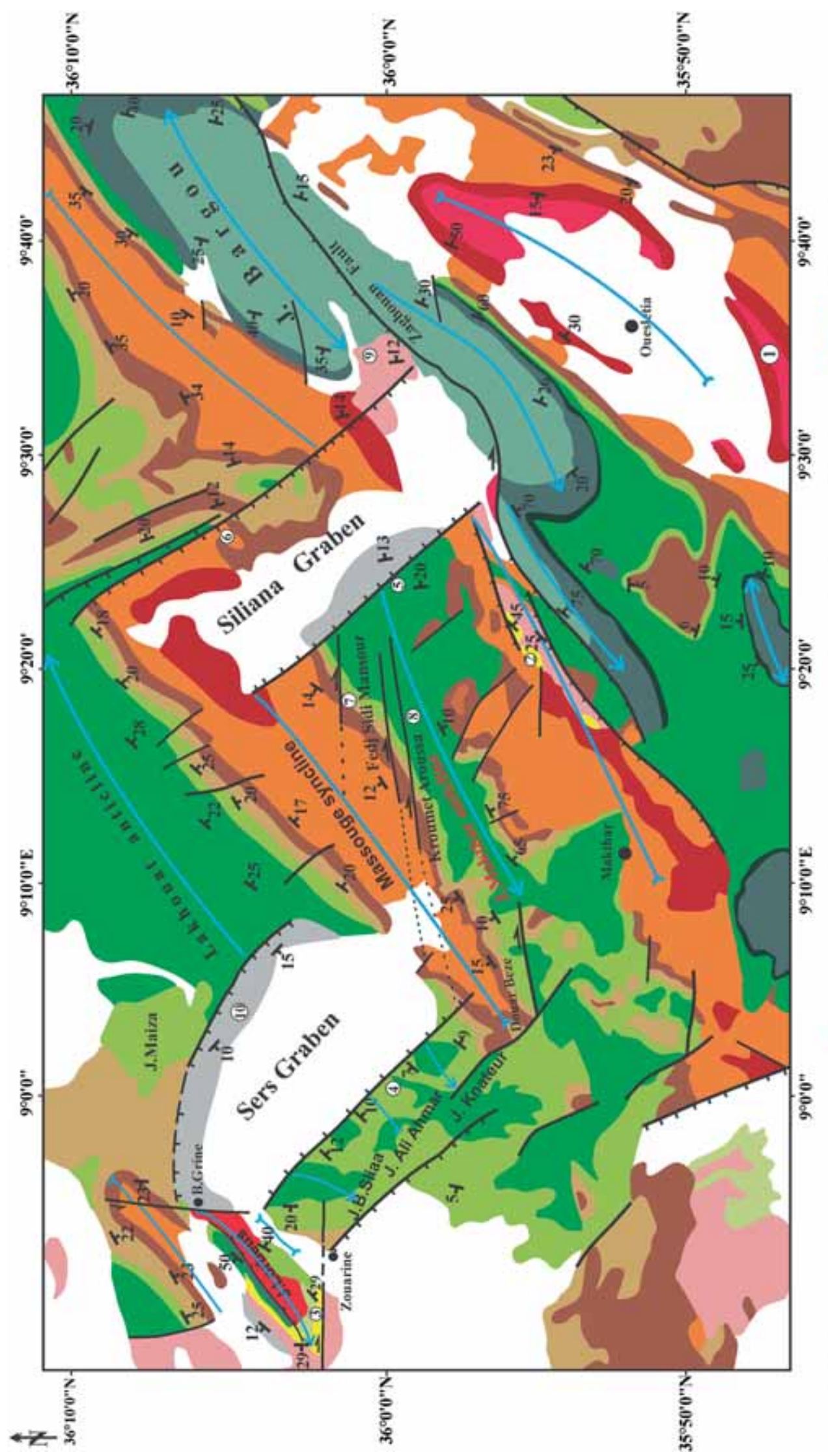

IIIIIH

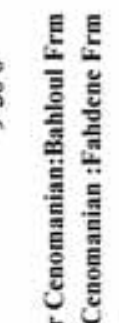

ถูป

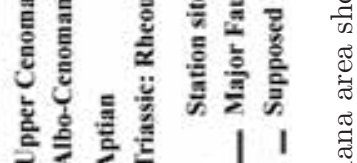

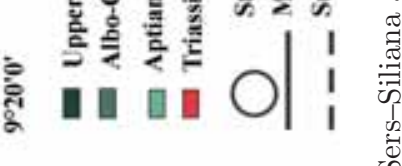

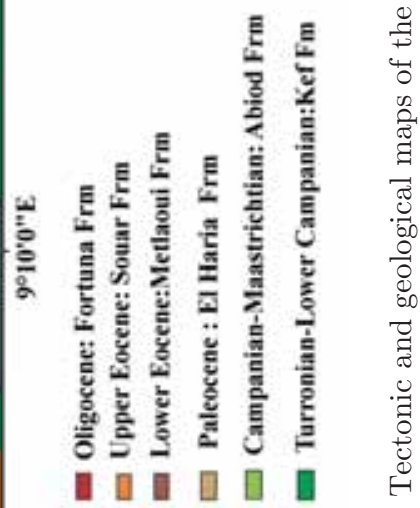

ํํำ

E

正产言产

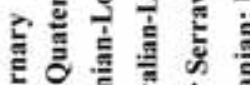

난

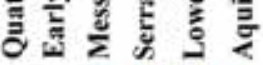

प० प्व 
domains. This mountain belt domain is one of the world largest intercontinental zones (Pique et al. 2002). The Tunisian Atlas domain is one of the key domains to establish the recent tectonic history of the North African margin because it summarises the tectonic processes that occurred during the convergence between the African and Eurasian plates since $70 \mathrm{Ma}$ (Ben Ayed 1986; Bousquet and Philip 1986; Philip et al. 1986; Nocquet and Calais 2004; Jolivet et al. 2008; Essid et al. 2016). This domain has a conspicuous structural feature represented by a set of NW-SE and E-trending grabens, NE-striking fold axes and reverse faults. The complex structural scheme of the Tunisian Atlas domain is mainly a consequence of the polyphased Cenozoic reactivation of Mesozoic inherited faults (Ben Ayed 1986; Chihi and Philip 1998; El Ghali et al. 2003; Melki et al. 2011; Haji et al. 2014; Masrouhi et al. 2014; Gharbi et al. 2015; Amri et al. 2017). Indeed, the setting up of the Tellian thrust sheets and the foreland basin collapse, during the early-middle Miocene, was associated with the convergence between the Africa and Eurasian plates with a subduction process (Philip et al. 1986; Chihi and Philip 1998; Garcia et al. 2003; Nocquet and Calais 2004). However, since the late Miocene this subduction phenomenon was translated in a continental collision that generated, in the Tunisian foreland, a set of NE-trending folds that named Atlasic direction (e.g., Ben Ayed 1986; Chihi and Philip 1998; Essid et al. 2016). The structural background of the Sers-Siliana area that located in north-central Tunisia of the Tunisian Alpine chain (figure 1a and b) is underlined by NW-trending grabens (e.g., Sers and Siliana grabens) mainly sub-orthogonal to the major NEstriking Atlasic folds (e.g., Jebel Lakhouate and Jebel Makthar anticlines) (figure 2).

The north-central of Tunisia, which our study area is a part of, is very rich in Mesozoic and lower Cenozoic series. However, this area is characterised by the scarcity and/or gap of Miocene series in some zones. This gap of Miocene outcrop in this domain is mentioned by some authors (Jauzein 1967; Ben Ayed 1986; Yaich et al. 2000; Ait Brahim et al. 2002; Melki et al. 2011) as shown in figure 3. In the Sers-Siliana area the Miocene series are situated in the Jebel Lorbeus structure, in the northern limb of the Jebel Bellouta structure and in the core of the Ouesletia syncline (figure 2), and are represented by the Messiouta, Beglia, Saouaf and Segui formations. The Beglia and Saouaf formations are characterised by a clay-sandstone series with lignite. The Segui formation in the Sfina area is represented by torrential conglomerate deposits at its base, a thick unit of yellow sand and local conglomerates in the upper part. Toward the NW (Jebel Lorbeus) this lithology seems to change, a little, and becomes rich in clays and red sands. A series of Segui formation (Messinian-lower Quaternary) are based on angular unconformity at the clay-sandstone series with lignite of the Saouaf formation (Serravalian-lower Tortonian). The Villafranchian deposits that occupy, in some places, the periphery of the Sers and Siliana grabens show smaller dip angles $\left(10-15^{\circ}\right)$ as well as near the Jebel Lorbeus structure.

\section{Major structures}

Precise geological mapping is one of the most important elements in geological studies. Documenting the spatial distribution of geologic structures (grabens, faults and folds) and their contacts between them play an important role in the interpretation of the structural evolution of any region. The detailed structural map of the Sers-Siliana region shows the complex arrangement of compressional and extensional structures (figure 2). Structures shaping the Sers-Siliana area fall into three categories: (i) normal faults, (ii) strike-slip faults and (iii) folds. Concerning the brittle structures, numerous sites were identified where the sense of slip along brittle faults can be determined using structural kinematic indicators (e.g., Arboit et al. 2015). The sense of movement along the fault planes was deduced from numerous kinematic indicators that evidenced in some sites.

\subsection{Folds}

The core of the NE-trending Atlasic folds in the Sers-Siliana area is cored by Cretaceous and Palaeogene deposits (e.g., Jebel Makthar and Jebel Lakhouet anticlines; Massouge syncline) or by the Triassic outcrop (i.e., Jebel Lorbeus structure) (figure 2). The main characteristics of these structures are: the NE-striking direction, their unequal repetition in both the edge of the grabens (Sers graben) and the absence of the periclinal closure near the NW-trending faults. For example, the Lakhouate and Jebel Bou Sliaa anticlines are NE-trending and their cores are occupied by the Kef formation. These Atlasic folds are 


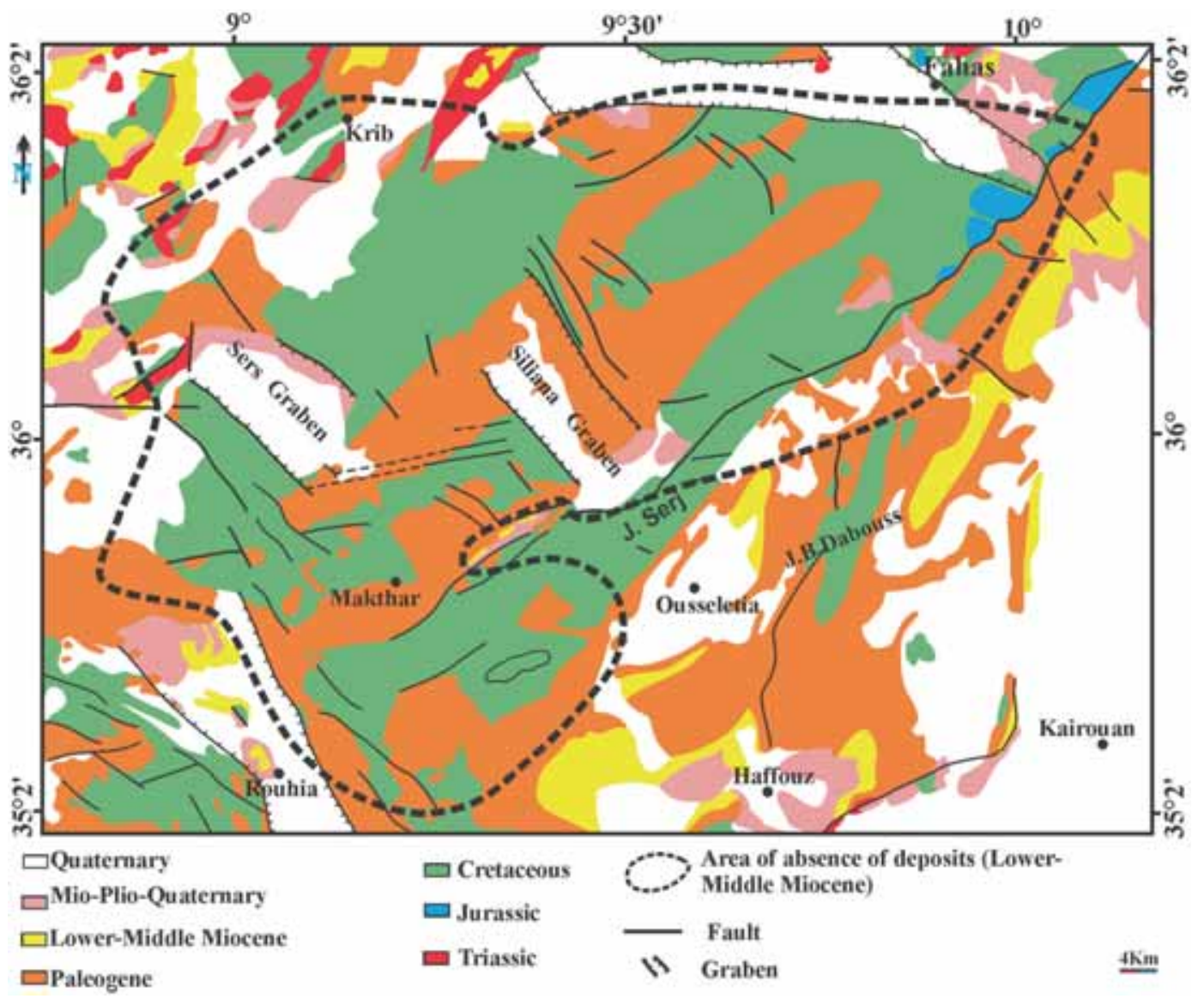

Figure 3. Geological map showing the areas of the absence of deposits (lower-middle Miocene) in the Sers-Siliana area.

characterised by the absence of the periclinal closure near the NW-striking faults that bounded the eastern and western edges of the Sers graben. This structural architecture is similar to that described by previous authors in the rest trough of the Tunisian foreland (e.g., Kasserine and Foussena grabens) (e.g., Ben Ayed 1986; Philip et al. 1986; Dlala 1995).

In addition, some NE-trending folds exhibit that certain portions of their flank are missing in direct contact with the border faults of the grabens. Field observations and the geological map show that the Massouge syncline is cored by the late Eocene strata (Souar formation), and is amputated from certain parts of these two flanks which are in direct contact with the Sers and Siliana grabens (figure 4).

\subsection{Faults}

\subsubsection{Normal faults}

The Sers-Siliana area is dominated by NW-trending major normal faults, $10-25 \mathrm{~km}$ in length, which affects Cretaceous, Palaeogene and Tertiary deposits. These faults, which dip to the northeast or southwest show sub-vertical planes, and border the Sers and Siliana grabens. The western side of the Sers graben is limited by NW-trending normal faults which dip to the northeastern and extends from the Jebel Lorbeus anticline until Massouge syncline. Near this normal fault, the Jebel Bou Sliaa anticline begins with an NE-SW axis strike and changes towards the NNE-trend (figure 2). In addition, in the eastern side of the Sers graben, a major NW-trending normal fault juxtaposed the deformed early Quaternary series with the late Cretaceous deposits (Abiod formation). At this locality, we observe a major NW-trending fault plane which shows sub-vertical slickenlines (stria pitching $80^{\circ}$ ) with dip-slip normal displacement (figure 5a and $\mathrm{a}^{\prime}$ ). On the other hand, the western and eastern edges of the Siliana graben are affected by two major NW-trending normal faults, which dip towards northeast and southwest, respectively. In the eastern side, we observe a normal fault that juxtaposed the lower Eocene series (Metlaoui formation) in structural contact with the late Eocene 


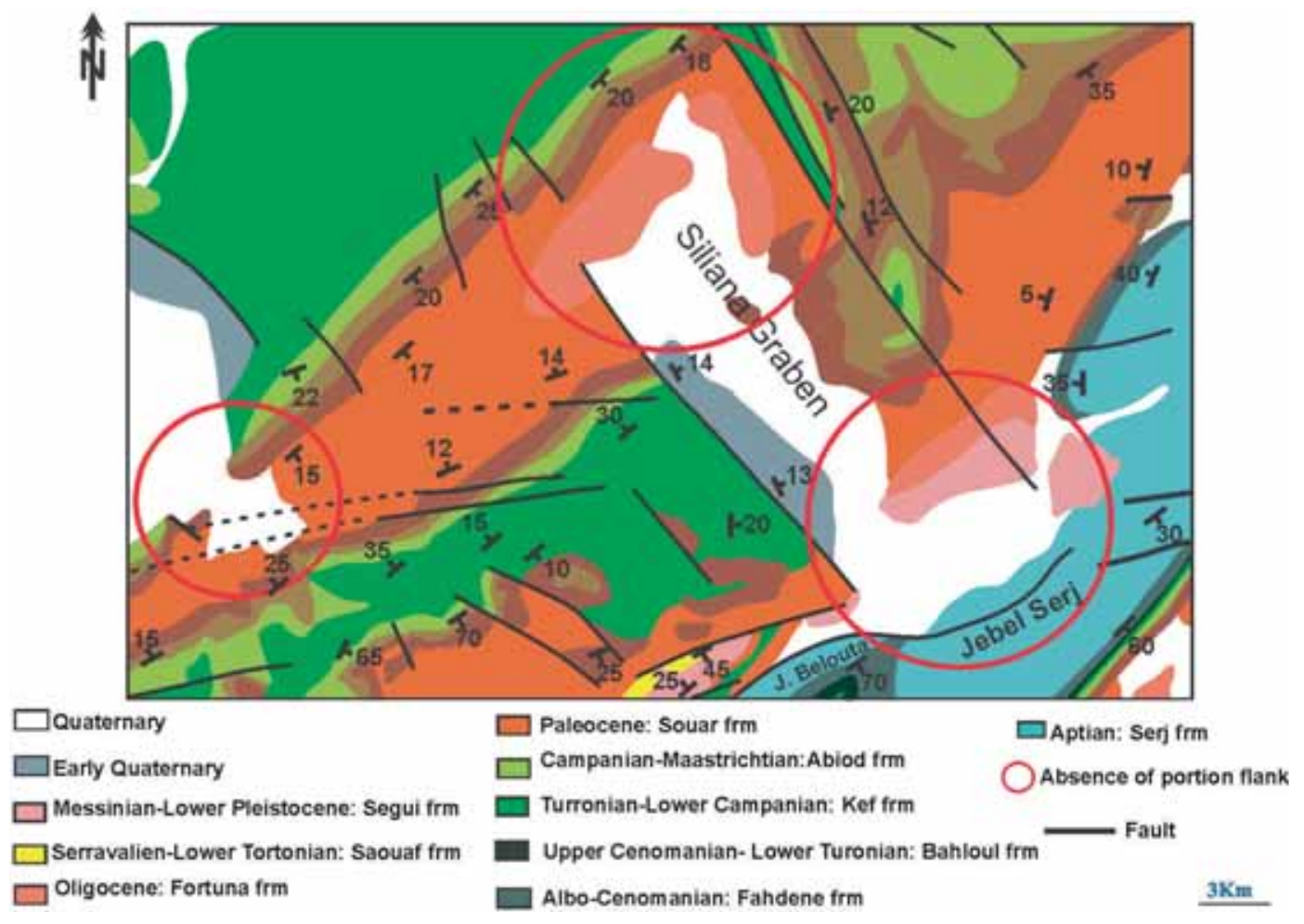

Figure 4. Absence of certain flank portions of the NE-trending folds in the Sers-Siliana area.
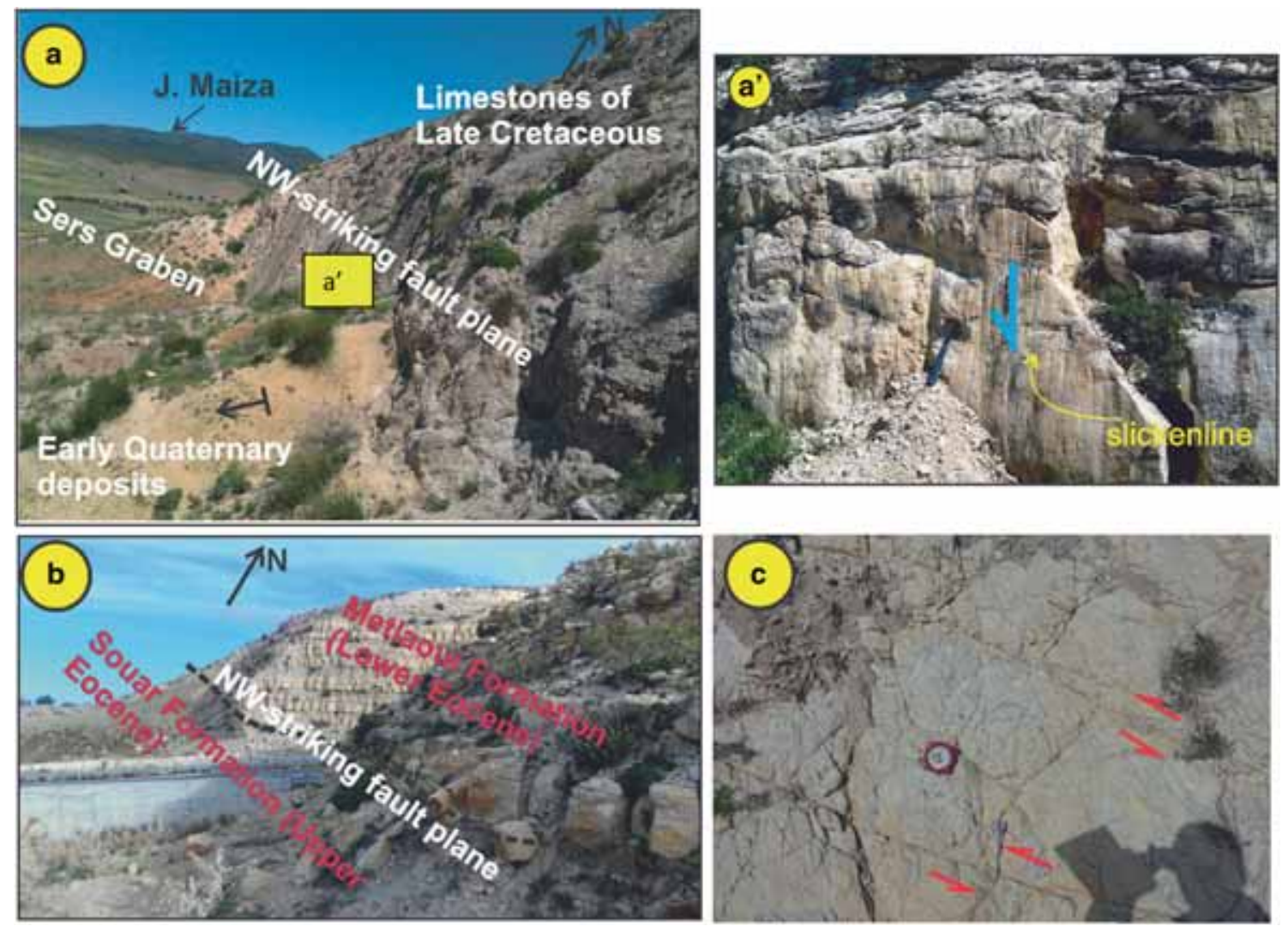

Figure 5. Photos illustrating the NW-striking faults: (a) panoramic view of the eastern edge of the Sers graben and the mechanical contact between upper Cretaceous and the early Quaternary deposits, $\left(\mathbf{a}^{\prime}\right)$ close-up view of the fault plane showing the slickenside on the slip surface indicating pure normal faulting with a pitch of $\sim 80^{\circ},(\mathbf{b})$ panoramic view of the eastern edge of the Siliana graben, and (c) close-up view of the fault plane showing strike-slip displacement. 
strata (Souar formation). The NW-trending fault planes show a sinistral strike-slip movement evidenced by the reactivation of mesoscale fractures (figure $5 \mathrm{~b}$ and $\mathrm{c}$ ).

Additional observations show that, in some localities, the NW-trending mirror faults show two generations of stria. The first generation of striae is stronger, indicating a normal movement and is cut by second stria (second generation) showing sinistral strike-slip component.

\subsubsection{Strike-slip faults}

The northwestern limit of the Sers graben shows a submeridian sinistral strike-slip fault located north of Bougrine city, putting the Triassic salt in contact with the middle Cretaceous deposits (Bahloul formation) (figure 2). South of Jebel Lorbeus the Neogene deposits are affected by an E-trending dextral strike-slip fault (figure 2). This latter forms the junction between the Sers and Kef grabens (Chihi 1995). In addition, previous studies on the Lorbeus area indicate the existence of the E-trending fault (Jauzein 1967). South of Elles city (Douar Beze) an important E-W dextral strike-slip fault brings the lower Campanian limestones (kef formation) in contact with the Campanian-Maastrichtian series (Abiod formation). Further east of the Massouge syncline, the E-striking dextral strike-slip fault of Kroumet Aroussa come in contact with the Campanian-Maastrichtian limestones and the Palaeocene black clays (El Haria formation). The plane of this fault shows two generations of stria (figure 6a and b). Similarly, in the Sidi Mansour region another E-W fault of the same importance brings the Ypresian limestones in contact with the Palaeocene black clays and shows tectonic breccias at places. At this locality, the mirror fault shows a dextral strike-slip movement evidenced by the reactivation of older subvertical calcite veins (figure $6 c$ and d).

From a facies point of view the Ypresian limestones, outcropping along the southeastern flank of the Massouge syncline, shows a facies variation upon three different facies; the first is nummulitic at Kalaat el Harrat (Jauzein 1967), the second is intermediate at the Sidi Mansour region and the third is Globigerina-rich in the Massouge region (Ben Ayed 1975). This facies variation indicates the palaeogeographic role played in these $\mathrm{E}-\mathrm{W}$ faults during the Eocene deposits (Jauzein 1967; Ben Ayed 1975).

The E-trending fault planes show two generations of slickensides (stria) with a significant horizontal component. The first one with an oblique component with normal-dextral displacement; the second stria cut the first one and shows a pure dextral strike-slip movement (e.g., figure 6b).

\section{Tectonic analysis and chronology of events}

In order to solve the ambiguity of the tectonic event chronology caused by the Miocene sedimentary gap in the Sers-Siliana area, two fields of study throughout the gap area were compared.

\subsection{Palaeostress analysis}

The adjacent regions of the Sers-Siliana grabens show the existence of the Miocene series recording perfectly the indexes of the tectonic regime that prevailed during that time. Regarding the reconstruction of the palaeostress axis of the Sers-Siliana area during the Neogene-Quaternary episode, the outcropping stratigraphic succession comprises the Miocene deposits outside the bald zone, which is characterised by a lithology rich in marls, sands and conglomerates that prevent us from observing specific streaks. For this reason the palaeostress analyses of the faults which affected these deposits were specifically analysed where the poles of the syn-depositional faults allow us to know the direction of the tectonic deformation. For the rest of the station sites, the analyses are carried out inside the bald zone using the numerical method and the improved 'Right Dihedron Method' (Delvaux and Sperner 2003). These deposits (in the bald zone) constitute an ideal laboratory for the reconstruction of the palaeostress because a majority of the faults are capable of preserving the tectonic deformation markers such as slickenside and tension joints. The measured fault-slip data in the Sers-Siliana area consist of fault plane orientations, dip directions and senses of slip.

\subsubsection{Extensional tectonics}

Outside the Sers-Siliana area, NW-trending synsedimentary normal faults were observed 

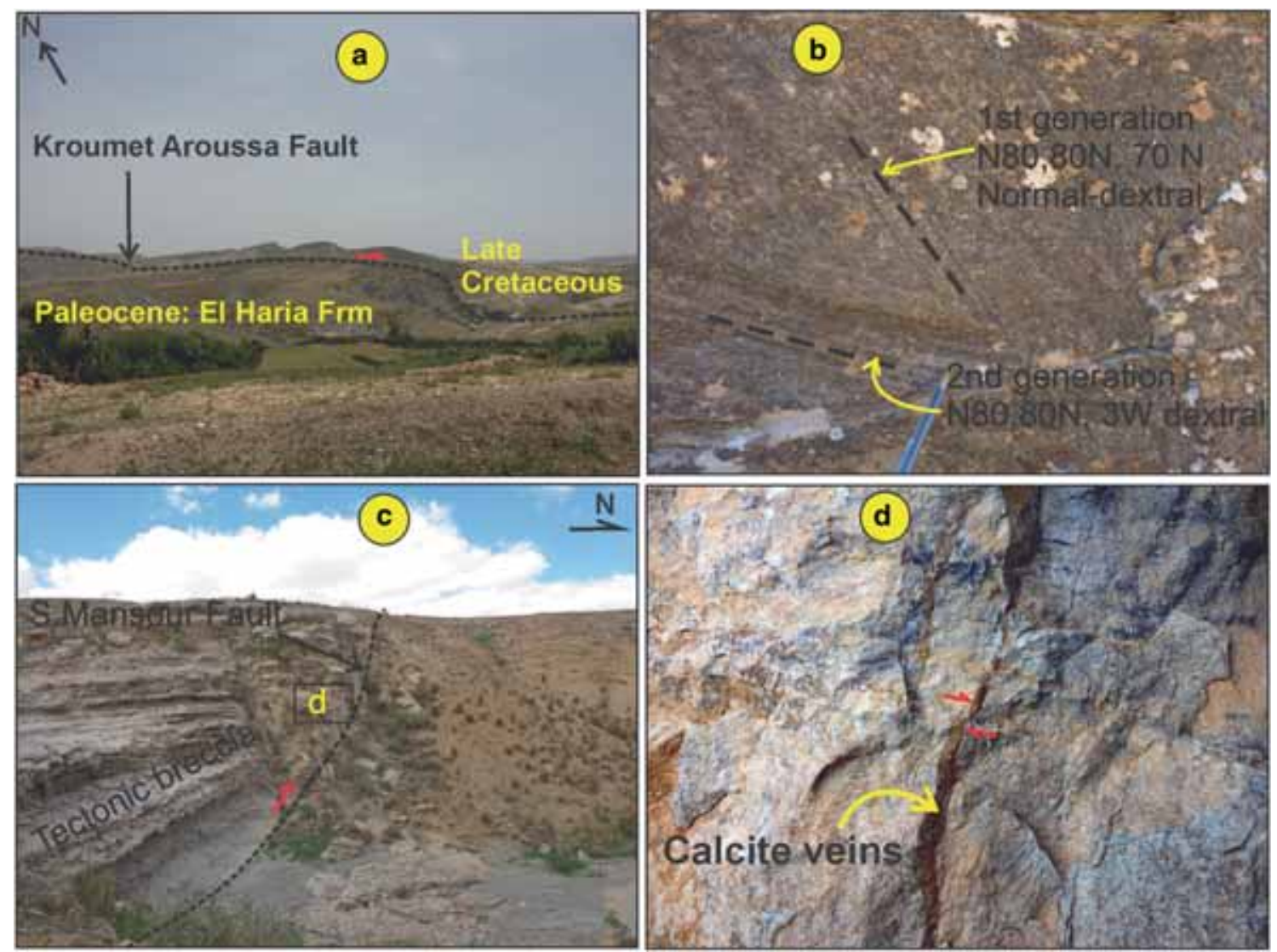

Figure 6. Photograph illustrating field view from the E-W-oriented strike-slip fault zone between the Sers and Siliana grabens: (a) Kroumet Aroussa fault; (b) successive oblique and dextral strike-slip striae on a E-striking fault plane, (c) the E-W-trend Sidi Mansour fault, and (d) E-trending fault shows a dextral strike-slip movement.

sometimes arranged in horst and grabens that affected the early Miocene deposits (figure 7a-g). South of our study area, in the region of Ouesletia, N140 and 170 decimetric to metric synsedimentary normal faults were observed, affecting the Aquitanian fine sands and red clays (Messiouta formation). In the Sfina region (SW of the Siliana graben) the lower Serravalian-Tortonian alternation of clays and lignite sands (Saouaf formation) is affected by a set of normal synsedimentary faults showing a lateral thickness variation. Furthermore, NW of our study area, south of Jebel Lorbeus anticlines and the lower-middle Miocene series also show the existence of NW-striking synsedimentary normal faults. The microtectonic analysis, by the graphical method, of these faults shows a NE-trending extensional phase (figures 8, S1, S2 and S3).

On the other hand, near the NW-trending major faults (inside the bald zone), the stress tensor solutions showed that the principal extension axis $\left(\sigma_{3}\right)$ is sub-horizontal with a NE-SW orientation; while $\sigma_{1}$ is subvertical, that proved to be an extensional tectonic phase with the NE-trend (figures 8, S4, S5 and S6).

\subsubsection{Compressional tectonics}

During the upper Miocene, a major NW-trending compressional phase affected the Sers-Siliana, which was recorded by the angular unconformity between the deposits of the Saouaf (Serravalian-Tortonian) and Segui formations (Messinian-lower Pleistocene) (figure $7 \mathrm{f}$ ). This first Neogene shortening may be responsible for the reactivation of the pre-existing faults in our study area. The stress tensor solution of the site stations showed a compressional regime with $\mathrm{NW}$-trending $\sigma_{1}$ and revealed a homogenous stress field appearing significantly homogenous across the study area including the NE-trending compressional structures (figures 8, S7, S8 and S9). Inside the Sers graben, we observe some mesoscale reverse faults with NE-trend that affected the early Quaternary deposits (figure $7 \mathrm{~h}$ ). The microtectonic analysis of the site S10, by the 

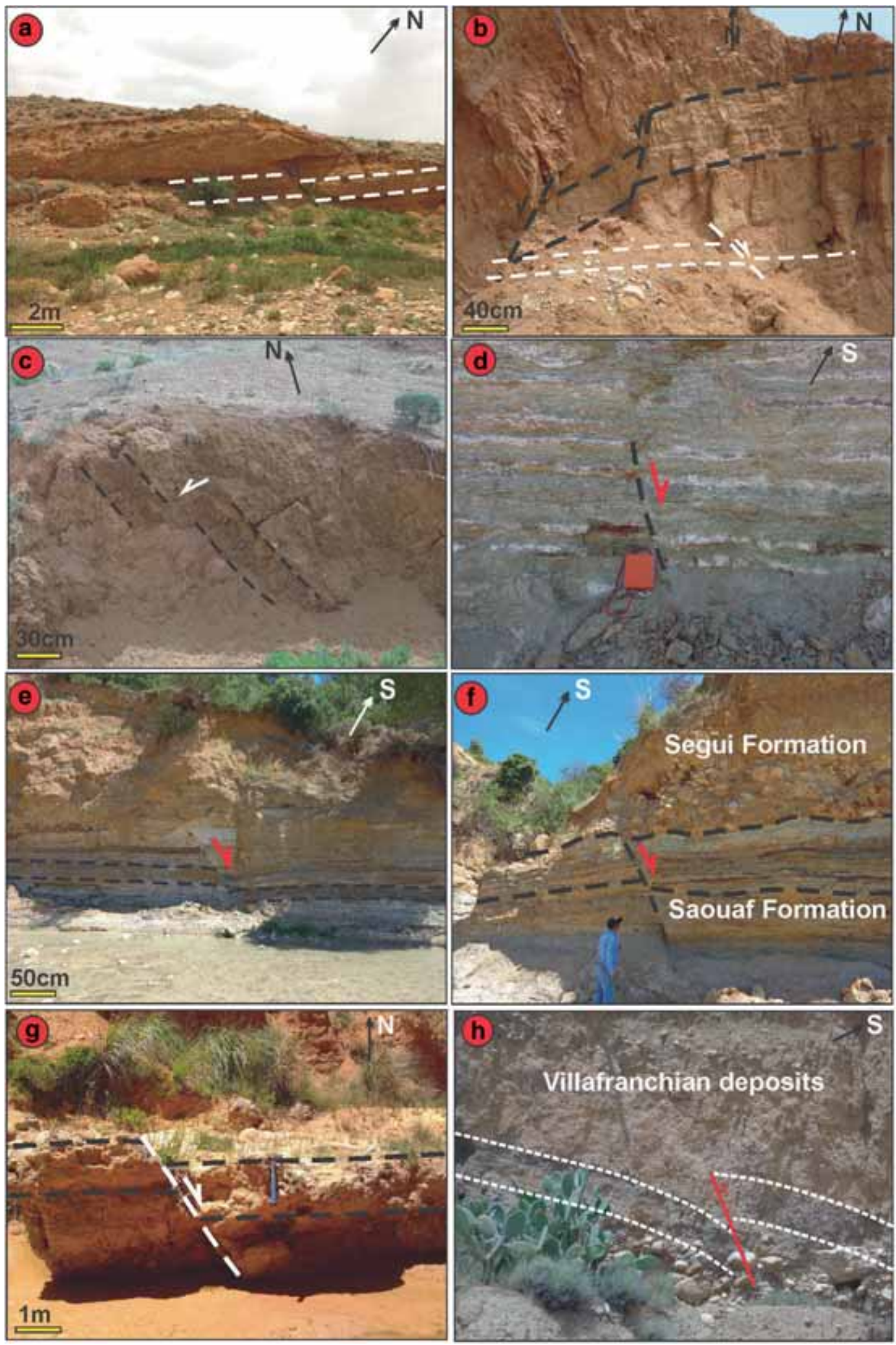

Figure 7. The extensional and compressional structures in the Neogene-Quaternary strata: (a-g) synsedimentary normal faults in the lower-middle Miocene deposits dominated by NW-SE extensional, and (h) mesoscale NE-trending reverse faults in the early Quaternary deposits.

graphical method of these NE-trending reverse faults, shows a NNW-SSE-trending compressional phase (figures 8, S10). This second Neogene shortening is evidenced by the deformation of the early Quaternary strata (figure 9a) and by an angular unconformity (figure 9b). 


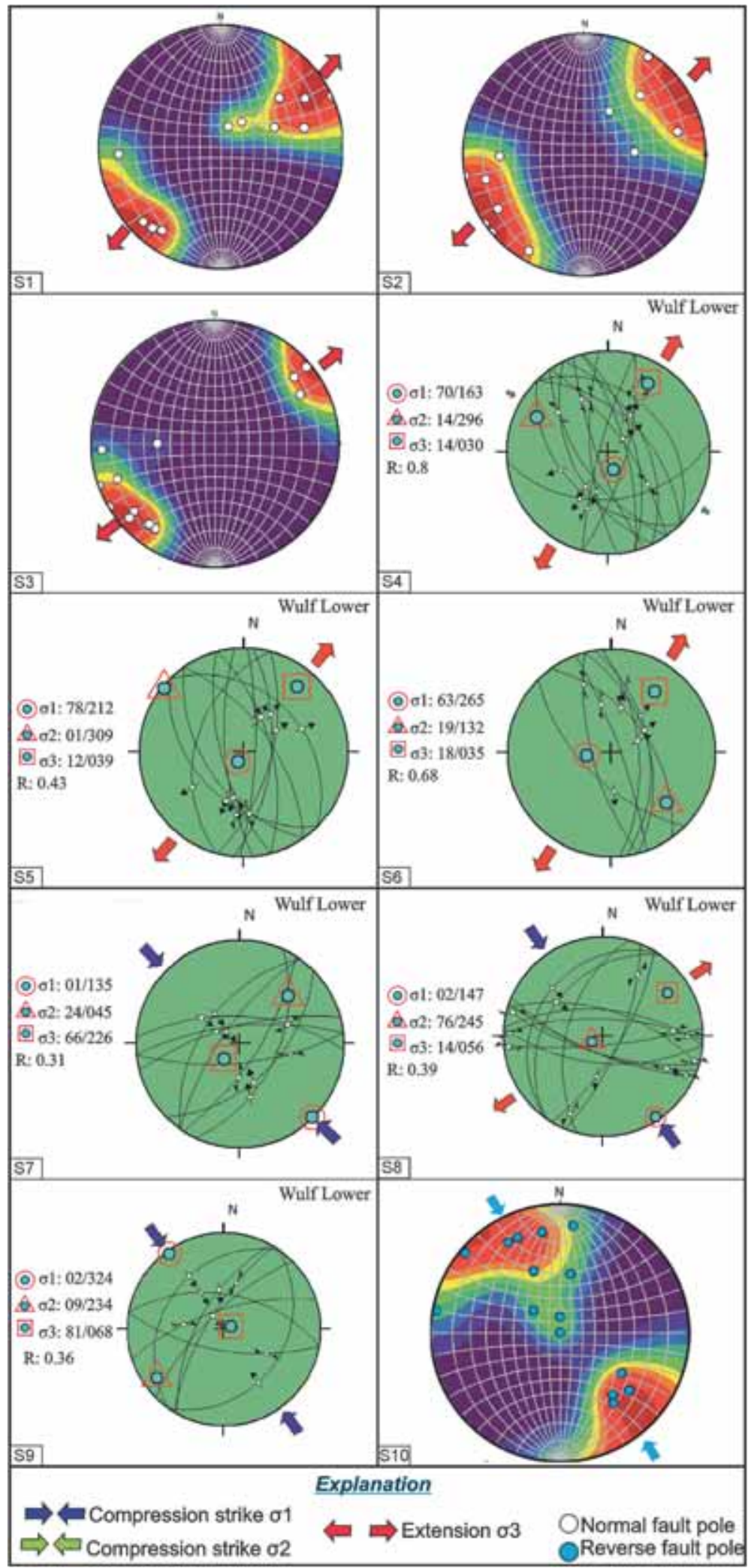

Figure 8. Tensor solution in the Sers-Siliana area.

\subsection{Tectonic study of Sers and Siliana grabens}

The lack of Miocene deposits in these grabens hides certain tectonic events that were not recorded nor inside the grabens neither at their immediate contacts. This lack of information led us to confront local and regional field data. Thus, the imbrications of compressional and extensional structures show NE- 

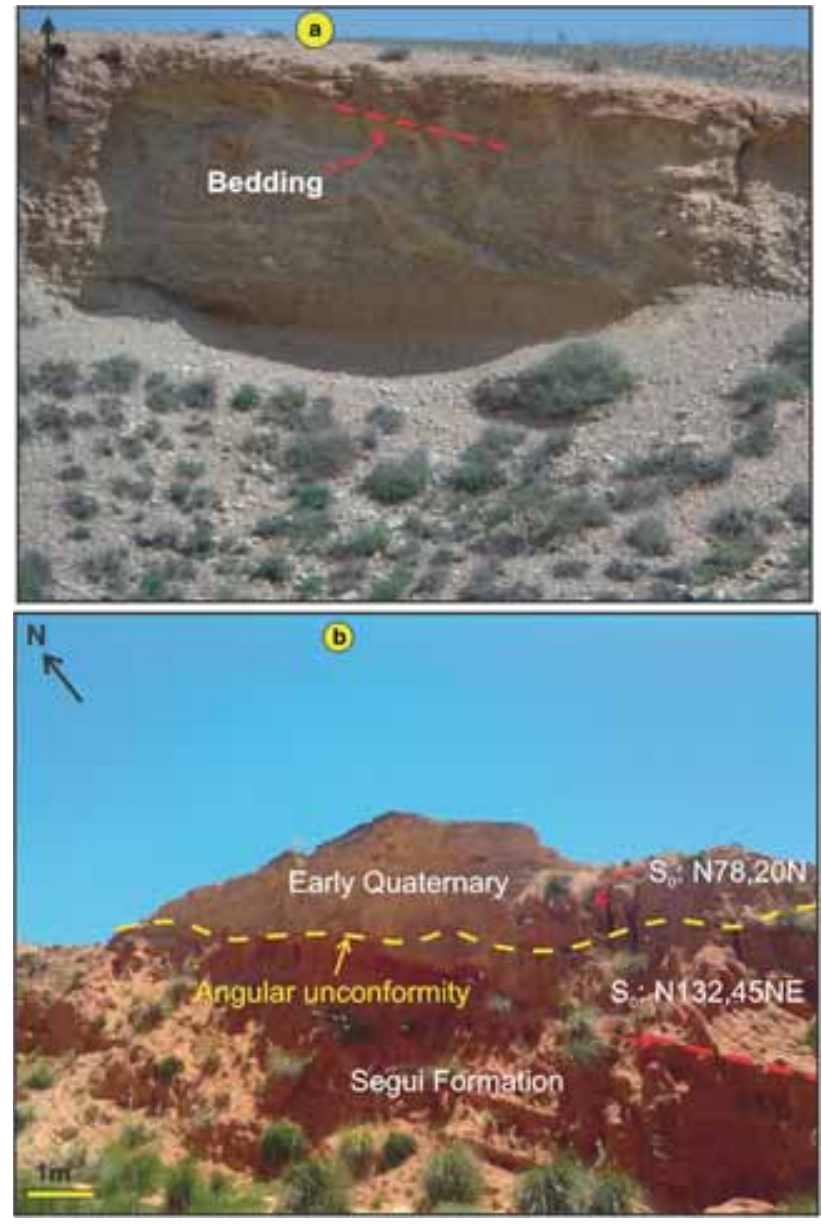

Figure 9. Photos showing: (a) the deformed early Quaternary deposits inside the graben and (b) close-up view of the angular unconformity between the deformed Segui formation of Messinian-lower Quaternary age and the early Quaternary deposits.

trending Atlassic folds abruptly cut by the graben faults showing no periclinal closures as for the Jebel Makthar, Lakhouate and Bou Sliaa anticlines (figure 2). Also, some folds show the absence of flank portions such as the Massouge syncline on its NW flank in contact with the Sers graben and its SE flank in contact with the Siliana graben. In addition, the Jebel Serj structure does not show a NW flank in contact with the Siliana graben. Thus, the absence of periclinal closure and some flank portions of the NE-striking folds indicate that the extensional structures predate the compressional one (NE-trending folds) (figure 4).

\section{Role of material rheology on the behaviour of E-trending faults in the NW-striking graben junction zone}

For a long time, the junction between the Siliana and Sers grabens has caused a major problem for the authors who considered that the two structures are not linked by faults. This has even led other authors to interpret them as two isolated basins and not grabens (Jauzein 1967; Richert 1971; Ben Ayed 1975). Our observation carried out between these structures shows that the major part of the junction zone is largely formed by the upper outcrop Eocene marls (Souar formation) of the Massouge syncline (figure 10a and b). However, a small outcrop of the late Cretaceous limestone located to the east, near the Siliana graben shows visible dextral E-trending faults that are truncated abruptly against the plastic marls of the Massouge syncline towards the west (figure 10c). This abrupt contact of these faults between the western border of the Siliana graben and the upper Eocene plastic marls to the west drew our attention to a probable continuity of these faults in the plastic marls. Based on the rheological arguments, which do not clearly show the continuity of the faults in the ravines uncovering, the lower Eocene limestones showing clearly the passage of the E-trending faults. Our investigation obviously shows that the clear passage of these E-W faults in the marls is attested by a visible strike-slip fault affecting the underlying Ypresian limestones (figure 10) apparently hidden by the overlying marls. These observations confirm the fault linkage of the two grabens and call into question the hypothesis of 'isolated basins' (Jauzein 1967; Richert 1971; Ben Ayed 1975). This observation confirms the fault junction of the Siliana-Sers grabens and supports the hypothesis of the relay grabens of the Tunisian Atlas proposed by Chihi and Philip (1998).

\section{Discussion}

A detailed structural and cartographic analysis carried out in the Sers-Siliana area has enabled to establish the recent structural evolution during the Neogene-Quaternary time of the NW-striking Sers and Siliana troughs described as the NW-trending isolated basin (Jauzein 1967; Richert 1971; Ben Ayed 1975). With regard to the absence of Miocene deposits, the recent chronology of the deformation events established was obtained from the megastructural distribution and the detection of synsedimentary tectonics in the Miocene strata near the Sers-Siliana area. Figure 11 summarizes the tectonic chronology of the Sers-Siliana area since the lower Miocene until Quaternary time. It reconstructs from the geometry and tectonic analysis of the major structures (NE-trending folds and 

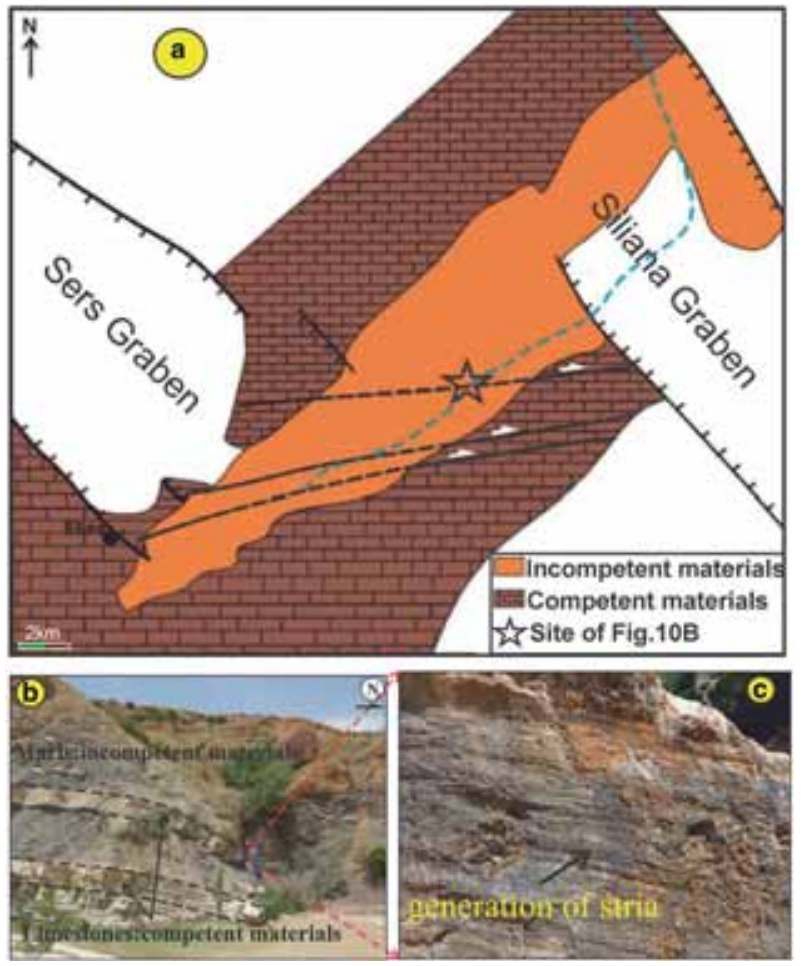

Figure 10. Illustration of the fault propagation in different mechanical layers: (a) geological map explains the propagation of the E-trending fault in incompetent and competent layers; (b) example of fault propagation in incompetent and competent materials, and (c) close-up view of the E-striking fault mirror showing slickenside on the slip surface indicating dextral strike-slip kinematic (striae pitching $\sim 7^{\circ}$ ).

NW-striking grabens), the relationship between them and based on the spatial distribution of the strain axis established from palaeostress analysis.

The NE-trending extensional phase, during the lower-middle Miocene, proved by the graphical palaeostress analysis, as well as by the numerical method inside the bald zone (figures 8, S1, S2, S3, $\mathrm{S} 4, \mathrm{~S} 5$ and $\mathrm{S} 6$ ) is recorded by several studies in the Tunisian foreland (Belguith et al. 2011; Melki et al. 2011; Azizi et al. 2015; Mahmoudi et al. 2016; Bejaoui et al. 2017). The absence of periclinal closures and portion flanks as well as the not-continuity of the major NE-trending Atlasic folds on both sides of the grabens (i.e., Sers graben) are explained by the significant subsidence of Miocene inside these structures.

These arguments at different scales, as described above, lead us to suggest that the first collapsing episode of the Sers and Siliana grabens was triggered during early Miocene. This NE-trending extensional phase associated with strike-slip deformation is responsible for the opening of the Sers-Siliana grabens where the E-trending dextral-
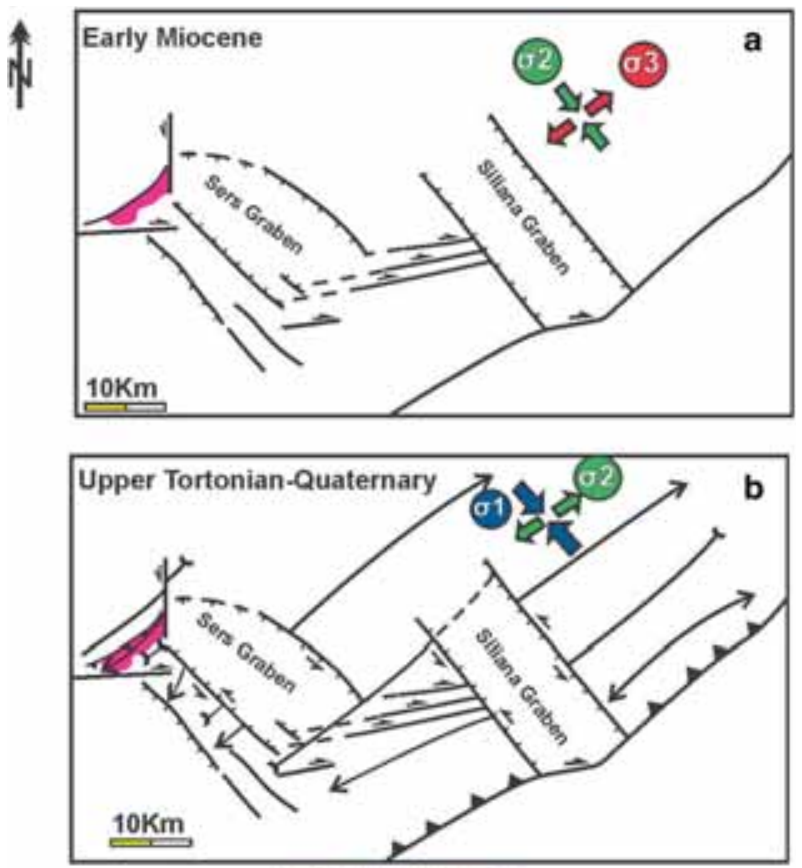

EXPLANATION

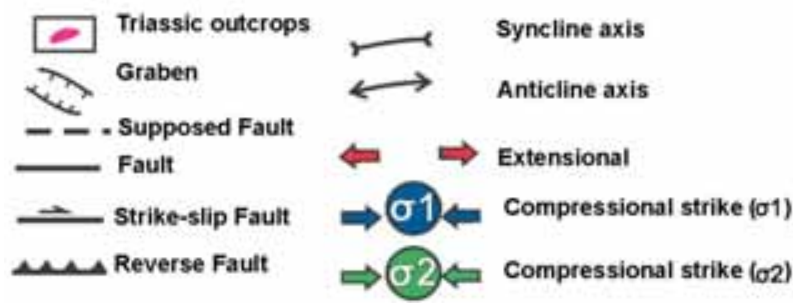

Figure 11. Chronology of tectonic events from lower Miocene until Quaternary of the Sers and Siliana grabens.

strike faults between them has assured the genetic link of these structures (figure 11a). This collapse timing has been proved in several studies on the Tunisian Atlas domain (Philip et al. 1986; Chihi 1995; Dlala 1995; Chihi and Philip 1998; Azizi et al. 2015). In addition, the structural scheme that corresponded to a relay system of the Sers and Siliana grabens is also proved in some graben structures of Tunisia (Chihi 1995) and at the Mediterranean scale, e.g., with the Graben of Pentaleria and Malta (e.g., Reuther and Eisbacher 1985; Chihi and Philip 1998).

Since the late Miocene (upper Tortonian), the Sers-Siliana area was affected by a major NWtrending compressional phase marked by the angular unconformity between the Saouaf (Serravalian-lower Tortonian) and Segui (Messinian-lower Quaternary) formations (figure 7f). This NW-striking shortening is responsible for the formation of the NE-trending fold axis, with one periclinal closure (e.g., Bou Sliaa anticline) as well 
as the reactivation of the pre-existing faults. Indeed, the E-trending pre-existing faults were reactivated as pure dextral strike-slip faults (figures 8, S8). This reactivation caused the torsion of the Lorbeus anticline with an E-striking axis near this fault (figure 2). However, the NWtrending shortening also induced the reactivation of the pre-existing NW-striking faults that subparallel to the $\sigma_{1}$ in normal-oblique faults with sinistral kinematic displacement (figure 11b). Indeed, the reactivation of the NW-trending fault of the western side of the Sers graben which leads to the change in the trend of the Bou Sliaa anticline from the NE to NNE-trend (figure 2).

The second-Neogene compression, in our study area, corresponds to the early Quaternary episode that proved by the deformed Segui and Villafranchian deposits. This compressional is oriented NNW as shown by the graphical microtectonic analysis (figures 8, S10). It is known in Tunisia by the post-Villafranchian shortening and is proved in our study by the angular unconformity as illustrated in figure 9 .

In our study area, the transition from the NEtrending extensional phase (lower-middle Miocene) to the NW/NNW-trending compressional phase (late Miocene-Quaternary) is materialised by the permutation between $\sigma_{2}$ and $\sigma_{1}$, respectively (figure 11). At a North African margin scale, a translation between subduction and continental collision (e.g., Philip et al. 1986; Azizi and Chihi 2017) occurred.

\section{Conclusion}

The Miocene sedimentary basins of the Tunisian Atlas are strongly guided by active synsedimentary tectonics, sometimes associated with diapiric uprisings. These tectono-diapiric phenomena can form raised or bald zones characterised by the absence of Miocene deposits. The absence of these Miocene deposits is a major handicap for the reconstitution of the local tectonic event chronology. The Sers-Siliana area is characterised by a Miocene sedimentary gap. To solve this tectonic event chronology, during the Neogene-Quaternary episode, local and regional data were compared. At a regional scale, graphical palaeostress analysis carried out in the early Miocene series shows the NE-trending extensional phase. These faults fit perfectly with a NE-trending extension prevailing at that time.
Field observations also show angular unconformities between the Segui and Saouaf formations indicating a NW-trending compressional phase responsible for the formation of NE-striking folds in the region. At a local scale, the Sers-Siliana grabens, filled with some early Quaternary series, show NE-trending folds striking abruptly on the border faults of the grabens without periclinal closures and sometimes showing the absence of certain portions of flanks in contact with these extensional structures. These phenomena attest to the anteriority of the grabens compared to the late Miocene folding phase and not Plio-Quaternary as proposed by previous authors. On the other hand, the E-W junction between the marly-dominant Sers-Siliana grabens has prompted some geologist to ignore the junction between these structures. Our observations show the passage of the E-W faults between these grabens as confirmed by the fault shift in the limestones underlying the late Eocene marls. These same E-W faults are visible on the surface in the late Cretaceous limestones of the western margin of the Siliana graben. These extensional structures are part of a regional relay system. Furthermore, the contemporaneity of the opening of the Tunisian Atlas grabens during the early Miocene and the thrusting phase in the Tellian domain allow them to be integrated in a geodynamic context of continental subduction of the African plate under the Eurasiatic plaque. During late Miocene, the system evolves a collision phase as shown the Atlassic folding, the NE-trending thrust and the folding of the thrust sheets in the Tellian domain.

\section{Acknowledgements}

We would like to thank the Editor-in-Chief and the Editorial committee. We would also like to thank the two anonymous reviewers for the help in improving the clarity of the manuscript.

\section{References}

Ait Brahim L, Chotin P, Hinaj S, Abdelouafi A, El Adraoui A, Nakcha C, Dhont D, Charroud M, Sossey Alaoui F, Amrhar M, Bouaza A, Tabyaoui H and Chaouni A 2002 Paleostress evolution in the Moroccan African margin from Triassic to Present; Tectonophys. 357 187-205. 
Amri D T, Dhahri F, Soussi M, Gabtni H and Bédir M 2017 The role of E-W basement faults in the Mesozoic geodynamic evolution of the Gafsa and Chotts basins, southcentral Tunisia; J. Earth Syst. Sci. https://doi.org/10. 1007/s12040-017-0876-1.

Arboit F, Amrouch K, Collins A S, King R and Morely C 2015 Determination of the tectonic evolution from fractures, faults, and calcite twins on the southwestern margin of the Indochina Block; Tectonics 34 1576-1599

Azizi R and Chihi L 2017 Superposed folding in the Neogene series of the northeastern Tunisia: Precision of the upper Miocene compression and geodynamic significance; Int. J. Earth Sci. (Geol. Rundsch.). 106(6) 1905-1918.

Azizi R, Ali K and Lassaád C 2015 Neogene tectonic evolution in Northern Tunisia: Case of Chaouat-Mannouba area. Paleoseismic event associated; Arab J. Geosci. 8(10) 8911-8925.

Bejaoui H, Melki F and Zargouni F 2017 Structural evolution of Cenozoic basins in northeastern Tunisia, in response to sinistral strike-slip movement on the El Alia-Teboursouk Fault; J. Afr. Earth Sci. https://doi.org/10.1016/j. jafrearsci.06.021.

Belguith Y, Geoffroy L, Rigane A, Gourmelen C and Ben Dhia H 2011 Neogene extensional deformation and related stress regimes in central Tunisia; Tectonophys. 509 198-207.

Ben Ayed N 1986 Evolution tectonique de l'avant-pays de la chaine alpine de Tunisie de début du Mésozoïque à l'Actuel; Thesis Es Sciences, Univ. Paris Sud, France, 286p.

Ben Ayed N 1975 Cuvettes de Siliana et du Sers. Thèse 3eme cycle (Atlas Tunisien centrale); Thesis, Univ. Pierre et Marie. France, 82p.

Bouaziz S, Barrier E, Soussi M, Turki M M and Zouari H 2002 Tectonic evolution of the northern African margin in Tunisia from paleostress data and sedimentary record; Tectonophys. 357 227-253.

Boukadi N 1994 Structuration de l'Atlas de la Tunisie: signification géométrique et cinématique des nœuds et des zones d'interférences structurales au contact de grands couloirs tectoniques; Thesis Es Sciences, Univ. Tunis II, Fac. Sc. Tunis, 249p.

Bousquet J C and Philip H 1986 Neotectonic of the tyrrhenian Arc and Apennines: An example of evolution from island to collisional stages; In: The origin of arcs (ed.) Wezel C F, Elsevier, Amsterdam, pp. 305-326.

Caire A 1977 Interprétation tectonique unitaire de l'Atlas tunisien à fossés; C.R. Acad. Sci. D 284(4) 349-352.

Castany G 1948 Les fossés d'effondrement de la Tunisie. Géologie et hydrogéologie. 1er fasc. Plaine de Grombalia et cuvettes de Tunisie orientale; Notes Serv. Géol. Tunisie 60 126-139.

Chihi L 1995 Les fossés néogènes à quaternaires de la Tunisie et de la mer pélagienne: leur étude structurale et leur signification dans le cadre de la Méditerranée centrale; Thesis Es Sciences, Univ. Tunis II, Fac. Sc. Tunis, 324p.

Chihi L and Philip H 1998 Les fossés de l'extrémité orientale du Maghreb (Tunisie et Algérie orientale): tectonique MoiPlio-Quaternaire et implication dans l'évolution géodynamique récente de la Méditerranée occidentale; Notes Serv. Géol. Tunisie 64 103-116.

Cohen C R, Schamel S and Boyd-Kaydi P 1980 Neogene deformation in Northern Tunisia: Origin of the eastern atlas by microplate-continental margin collision; Bull. Soc. Geol. France 91 225-237.

Delvaux D and Sperner B 2003 Stress tensor inversion from fault kinematic indicators and focal mechanism data: The TENSOR program; In: New insights into structural interpretation and modeling (ed.) Nieuwland D, Geol. Soc. London, pp. 75-100.

Dhahri F, Tanfous D, Gabtni H and Boukadi N 2015 Structural and geodynamic study in Central Tunisia using field and geophysical data: New structural interpretation of the N-S axis and associated Atlassic structures; Int. J. Earth Sci. 104 1819-1835.

Dlala M 1995 Evolution géodynamique et tectonique superposées en Tunisie: implication sur la tectonique récente et la sismicité; Thesis Es Sciences, Univ. Tunis II, Fac. Sc. Tunis II, Fac. Sc. Tunis, 389p.

El Ghali A, Bobier C and Ben Ayed N 2003 Róle du système de failles E-W dans l'évolution géodynamique de l'avant-pays de la chaine Alpine de Tunisie. Exemple de l'accident de Sbiba-Cherichira en Tunisie centrale; Bull. Soc. Géol. France 174(4) 373-381.

Essid M, Kadri A, Inoubli M H and Zargouni F 2016 Identification of new NE-trending deep-seated faults and tectonic pattern updating in northern Tunisia (MogodsBizerte region), insight from field and seismic reflexion data; Tectonophys. https://doi.org/10.1016/j.tecto.2016. 05.032 .

Garcia E, Danobeitia J, Verge J, Bartolome R and Cordoba D 2003 Crustal architecture and tectonic evolution of the Gulf of Cadiz (SW Iberian margin) at the convergence of the Eurasian and African plates; Tectonics 22 10331058.

Gharbi M, Espurt N, Masrouhi A, Bellier O and Amari A 2015 Style of Atlassic tectonic deformation and geodynamic evolution of the southern Tethyan margin, Tunisia; J. Mar. Pet. Geol. 66 801-816.

Haji T, Dhahri F, Marco I and Boukadi N 2014 New insights on the tectonic and paleogeographic evolution of the central Atlassic domain of Tunisia; Arab J. Geosci. 7 1605-1616.

Jauzein A 1967 Contribution à l'étude géologique des confins de la dorsale tunisienne (Tunisie Septentrionale); Notes Serv. Géol. Tunisia 22 430-475.

Jolivet L, Augier R and Faccenna C 2008 Subduction, convergence and the mode of back arc extension in the Mediterranean region; Bull. Soc. Géol. France 179 525-550.

Karoui-Yaakoub N, Zaghbib-Turki D and Keller G 2002 The Cretaceous-Tertiary (K-T) mass extinction in planktic foraminifera at Elles I and El Melah, Tunisia; Palaeogeogr. Palaeoecol. 178 233-255.

Mahmoudi N, Ferhi F and Chihi L 2016 Tectonic and microtectonic study of the sers graben; In: Oral presentation in International conference on applied geology and environment in Mahdia, 19-12 May.

Masrouhi A, Bellier O and Koyi H 2014 Geometry and structural evolution of Lorbeus diapir, northwestern Tunisia: Polyphase diapirism of the North African inverted passive margin; Int. J. Earth Sci. (Geol Rundsch.). 103 881-900.

Melki F, Zouaghi T, Harrab S, Casas Sainz A, Bédir M and Zargouni F 2011 Structuring and evolution of Neogene transcurrent basins in the Tellian foreland domain, northeastern Tunisia; J. Geodyn. 52 57-69. 
Nocquet J M and Calais E 2004 Geodetic measurements of crustal deformation in the western Mediterranean and Europe; Pure Appl. Geophys. J. 16 66-681.

Philip H, Anderieux J, Dlala M, Chihi L and Ben Ayed N 1986 Evolution tectonique Mio-Plio-Quaternaire du Fossé de Kasserine (Tunisie centrale): Implication sur l'évolution géodynamique récente de la Tunisie; Bull. Soc. Géol. France 4 559-568.

Piqué A, Tricart P, Guiraud R, Laville E, Bouaziz S, Amrhar M and Ouali R 2002 The Mesozoic-Cenozoic Atlas belt (North Africa); Geodin. Acta 15(3) 185-208.
Reuther C D and Eisbacher G H 1985 Pantelleria rift-crustal extension in a convergent intraplate setting; Geol. Rundsh. 74 585-597.

Richert J P 1971 Mise en évidence de quatre phases tectoniques successive en Tunisie; Notes Serv. Géol. Tunisie 34 115-125.

Yaich C, Hooyberghs H J F, Durlet C and Renard M 2000 Corrélation stratigraphique entre les unités oligo-miocènes de Tunisie central et le Numidien; C.R. Sci. Paris 331(5) 499-506.

Corresponding editor: Arkoprovo Biswas 